\title{
The Effect of Realization of Regional Tax Revenue and Regional Retribution on Unemployment Rate With Moderation of Capital Expenditure
}

\author{
Prasetyo Yekti Utomo ${ }^{1}$, Priyanto ${ }^{2}$, Subiyantoro ${ }^{3}$, Srimiatun ${ }^{4}$ \\ State Polytechnic of Madiun ${ }^{1,2,3,4}$ \\ \{prasetyo@pnm.ac.id\}
}

\begin{abstract}
The handover of regional financial resources in the form of regional taxes and retributions as well as in the form of balance funds is a consequence of the handover of government affairs to regions which is carried out based on the principle of Autonomy. There is an estimate that the Fiscal Decentralization policy will improve the regional economy including Madiun City, and on the other hand, efforts to increase local government revenues, in this case an increase in local taxes and retributions, do not necessarily reduce unemployment, which is interesting and encouraging to be researched. This study aims to determine the effect of the realization of tax revenues and local retributions on the number of unemployed, as well as the effect of capital spending in moderating this relationship.This study uses a quantitative method with 10 years Time series data from 2010 - 2019. Data collection uses documentation techniques on data that have been published by the Central Statistics Agency and the Regional Financial and Asset Management Office of Madiun City. Data analysis used Linear Multiple Regression Analysis and Moderate Regression Analyzer (MRA) with software tools SPSS ver 20.The regression results on the independent variables with the dependent variable show that partially Tax (X1) has a negative effect, while Retribution (X2) has no effect on the Unemployment Rate (Y). Meanwhile, simultaneously, taxes and retributions have an effect on the unemployment rate (Y). The regression results with moderating variables show that the Capital Expenditure variable (M) does not moderate the relationship between the Tax (X1) and Retribution (X2) variables on the Unemployment Rate (Y).
\end{abstract}

Keywords: Tax, Retribution, Capital Expenditure, Unemployment Rate

\section{Introduction}

To carry out government affairs which fall under its authority, a region must have financial resources so that the region is able to provide services and welfare to the people in its region. The provision of financial resources to the regions must be balanced with the burden or government affairs assigned to the regions. The balance of this financial source is a guarantee for the implementation of government affairs that are delegated to the regions. When regions have inadequate financial capacity to finance government affairs and particularly mandatory 
government affairs related to basic services, the Central Government can use the DAK (Special Alocation Budget) instrument to assist the regions in accordance with the national priorities to be achieved. Regional financial management is regulated in the Regional Revenue and Expenditure Budget (APBD). Regional income comes from the original regional income, balance funds and other legal PAD, then the regional income is used by the region to finance regional expenditure.

Regional financial policies are aimed at increasing Regional Original Revenue as the main source of regional income that can be used by regions in implementing government and regional development according to their needs, in order to reduce dependence on obtaining funds from the top level government (subsidies). Thus, efforts to increase Regional Original Income should be viewed from a broader perspective not only from the perspective of each region, but in relation to the unity of the Indonesian economy. Original Regional Income is considered as an alternative to obtaining additional funds that can be used for various expenditure needs determined by the regions themselves, especially routine needs, therefore the increase in income is what every region wants [1].

The Madiun City Government, as one of the regional governments under the province of East Java, is able to increase its Regional Original Income (PAD) annually. The increase in Regional Original Income (PAD) is certainly expected to have a positive impact on the implementation of development in Madiun City. Regional spending is aimed at advancing the region and the welfare of its people, the more regional income that can be obtained, the more capable and independent the region will be to finance regional spending. In order to be more independent in a region, it requires awareness from the community to participate in contributing to Regional Original Income (PAD) through paying local taxes to paying local retribution.

To increase fixed assets, local governments allocate funds in the form of capital expenditures in the APBD. This capital expenditure allocation is based on regional needs for facilities and infrastructure, both for the smooth implementation of government tasks and for public facilities. Usually every year the local government procures fixed assets according to budget priorities and public services that have long-term financial impacts. There is an estimate that the fiscal decentralization policy will improve the regional economy including Madiun City, and on the other hand, efforts to increase local government revenue, in this case an increase in regional taxes and retribution, do not necessarily reduce unemployment, which is interesting and encouraging to be researched. This research is also motivated by differences in research results (research gaps) from previous studies that looked at the influence of PAD (local taxes and retribution) and capital expenditures on several dependent variables, including poverty level, economic growth and unemployment rate.

Based on the background developed above, it can be seen that there are several problems to be examined in this study, namely:

a) Does the realization of local tax revenue affect the unemployment rate?

b) Does the realization of retribution income affect the unemployment rate?

c) Does the realization of tax and user fees affect the unemployment rate?

d) Does capital expenditure moderate the effect of local taxes on the unemployment rate?

e) Does capital expenditure moderate the effect of local user fees on the unemployment rate? 


\section{Theoritical Review}

\subsection{Regional Autonomy Theory}

Mardiasmo provides an opinion that in the era of regional autonomy it is no longer just carrying out instructions from the center, but actually has the flexibility to increase creativity in developing potential.[2] The regional government is expected to be more independent, reduce dependence on the central government, not only related to financing, but also related to regional management capacity and is expected to further improve public services. According to Law Number 32 Year 2004 concerning Regional Government Article 1 paragraph 5. "Regional autonomy is the right, authority and obligation of an autonomous region to regulate and manage government affairs and the interests of local communities in accordance with statutory regulations".

\subsection{Fiscal FederalismTheory}

The concept of Fiscal Federalism explains that budget decentralization will allow local governments to better know information on local needs and resources. This knowledge will enable local governments to empower and allocate resources (local accountability) in the form of budgets for the achievement of community welfare. Local governments will also be very wise in making public economic decisions.[3] Public economic decisions include the role of local governments in the allocation and distribution of economic resources, to improve people's welfare.[4] The implementation of budget decentralization also makes it easier for local governments to mobilize and use local resources to improve public services.

\subsection{Fiscal Decentralization Theory}

According to Halim, fiscal decentralization in accordance with Law No.33 of 2004 concerning Financial Balance between the Central and Regional Governments is defined as the delegation of authority in the field of budget or financial revenue which was previously centralized, both administratively and its utilization is regulated or carried out by the central government. With the devolution of some of the authority over revenue sources in the regions, it is hoped that regions can carry out routine tasks, provide public services and increase productive investment (capital investment) in their regions.[5] Fiscal decentralization requires shifting some of the responsibilities for revenue and / or expenditure to lower levels of government. Fiscal decentralization must be accompanied by the ability of local governments to collect taxes (taxing power). [6] In theory, there is a tax capability, so the local government will have a large source of development funds. Taxes imposed by local governments can have a positive impact which will be used to build various infrastructure and finance various public expenditures.

\subsection{Regional Original Income (PAD)}

Regional Original Income, is revenue obtained by the region which is collected based on regional regulations in accordance with statutory regulations. In addition, according to Law No.32 of 2004, regional revenue is all regional rights recognized as an addition to net asset value in the period of the fiscal year concerned. Regional Original Income, namely: (1) local 
tax proceeds; (2) the results of local fees; (3) proceeds from the management of separated regional assets; and (4) other legal PAD;

\subsection{Local Tax}

Local taxes are mandatory contributions made by individuals or entities to regions without a balanced direct compensation, which can be enforced based on the prevailing laws and regulations, which are used to finance regional government administration and regional development [2]. Based on Law no. 28 of 2009 concerning Regional Taxes and Regional Retribution, the types of regency / city taxes consist of:
a) Hotel Tax;
b) Restaurant Tax;
c) Entertainment Tax;
d) Advertising Tax;
e) Street Lighting Tax;
f) Non-Metal Mineral and Rock Tax;
g) Parking Tax;
h) Groundwater Tax;
i) Tax on Swallow's Nest;
j) Rural and Urban Land and Building Tax; and
k) Fees for Acquisition of Rights on Land and Buildings.

\subsection{Regional Retribution}

Regional retribution arepayment for certain services or permits that are specifically provided and / or granted by the Regional Government for the benefit of individuals or entities (PP No. 69/2010). Based on the Act. 28 of 2009, the objects of retribution collected by regions consist of; (1) Objects for Public Service Retribution; (2) Objects for Business Services Retribution; (3) Certain Permits Retribution.

\subsection{Capital Expenditures}

Capital expenditure is a component of direct spending in the government budget which produces output in the form of fixed assets. In utilizing the resulting fixed assets, some are in direct contact with public services or are used by the community and some are not directly used by public (such as government office buildings). From a public policy perspective, most of the capital expenditures relate to public services, so that in each annual budget the amount should be relatively large. Capital expenditure is a regional government expenditure whose benefits exceed one fiscal year and will increase regional assets or wealth and subsequently increase routine expenditures such as operating and maintenance costs.

Capital expenditures are budget expenditures for the acquisition of fixed assets and other assets that provide benefits for more than one accounting period. To find out whether an expenditure can be included as a capital expenditure or not, it is necessary to know the definition of fixed assets or other assets and the criteria for capitalization of fixed assets.

Based on the explanation above, it can be concluded that an expenditure can be categorized as a capital expenditure if:

a) the expenditure results in the acquisition of fixed assets or other assets, thereby increasing government assets; 
b) the expenditure exceeds the minimum capitalization limit for fixed assets or other assets that have been determined by the government;

c) the acquisition of fixed assets is not intended to be sold.

Apart from capital expenditures for the acquisition of fixed assets and other assets, expenditures for expenses after the acquisition of fixed assets or other assets can also be included as capital expenditures. These expenditures can be categorized as capital expenditures if they meet the following requirements:

a) These expenditures increase the useful life, capacity, quality and volume of assets owned.

b) The expenditure meets the minimum capitalization value of fixed assets / other assets.

Regarding the first criterion above, it is necessary to know the following definitions:

a) The increase in useful life is the increase in the expected economic life of the existing fixed assets.

b) Capacity building is an increase in the capacity or capability of existing fixed assets.

c) Improved asset quality is an increase in the quality of existing fixed assets.

d) The increase in the volume of assets is the increase in the number or unit of measure of existing assets.

Capital expenditure consists of: (1) Fixed asset expenditure; (2) Expenditures for other fixed assets; (3) Expenditures for other assets; (4) Miscellaneous / Unexpected shopping; and (5) Transfer.

\subsection{Open Unemployment}

Unemployment is a macroeconomic problem that affects humans directly and is the most serious problem that will cause a decline in living standards and psychological stress.[7] According to Sukirno open unemployment is a workforce who really does not have a job.[8] This type of unemployment is quite a lot because they have not yet got a job even though they have tried their best and as a result the increase in job vacancies is lower than the increase in labor. The effect of this situation in a long enough period of time they do not do a job. So they are unemployed for real and part of the time, and hence it is called open unemployment. Open unemployment can also manifest as a result of declining economic activity, from technological advances that reduce the use of labor, or as a result of the decline in the development of an industry.

According to Mankiw, The unemployment rate can be calculated by comparing the number of unemployed with the total workforce expressed in percent. Unemployment rates that are too high can also cause political, security and social turmoil, disrupting economic growth and development.[7] The long-term result is a decrease in GNP and a country's per capita income. In developing countries like Indonesia, there is a term known as "underemployment", where work that should be done with less labor is done by more people. The number of unemployed is usually in line with the population growth and is not supported by the availability of new jobs or a reluctance to create jobs (at least) for themselves or it is not possible to get jobs or make it impossible to create jobs. According to Mankiw, the types of unemployment are as follows:

\section{a) Based on Working Hours}

1) Disguised unemployment is workers who can be said to be underemployed if they work less than 7 hours a day. 
2) Under unemployment is workers who do not work optimally because there are no jobs, usually this underemployed workers are workers who work less than 35 hours a week.

3) Open unemployment is workers who really do not have a job. This type of unemployment is quite a lot because they have not yet got a job, even though they have tried their best.

\section{b) Based on the cause of the occurrence}

1) Frictional unemployment is unemployment because workers are waiting for a better job.

2) Structural unemployment is unemployment caused by unemployed people looking for jobs who are unable to meet the requirements determined by job creation.

3) Technologycal unemployment is unemployment caused by technological developments / changes. This change can cause workers to be replaced in order to use the technology applied.

4) Cyclical unemployment is unemployment caused by an economic decline which causes the company to not be able to accommodate all existing workers. An example of this is because there are other similar companies operating or the purchasing power of products by the community has decreased.

5) Seasonal unemployment is unemployment due to fluctuating economic cycles due to changing seasons. In general, in agriculture and fisheries, farmers and fishermen are examples.

6) Total unemployment is unemployed who really do not get a job, because there are no jobs or opportunities to create jobs.

\subsection{Theoretical Framework}

This research will test the effect of local tax revenue and retribution on the unemployment rate with capital expenditure as a moderating variable, so that the relationship can be described as follows:

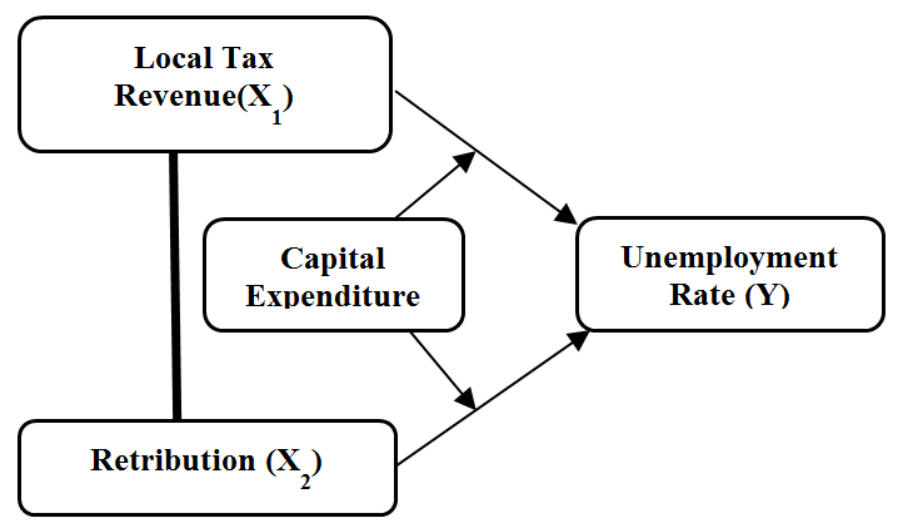

Fig. 1. Theoretical Framework

\subsection{Hypothesis}

The results of research conducted by Kresnandra in his research on the effect of local tax rates and retribution on the amount of unemployment and capital expenditures as moderator 
show that local taxes have a negative and significant effect on the unemployment rate.[9] Setiyawati states that unemployment is closely related to job availability, job availability is closely related.to capital expenditure or what is often called development spending.[10] Thus, the correct budget allocation strategy is to optimize the potential of development sectors through the allocation of local tax and retribution revenues which in turn can reduce unemployment by increasing economic growth in the regions. Based on these two opinions, the first hypothesis $\left(\mathrm{H}_{1}\right)$ can be derived as follows:

$H_{1}$ : Local taxes have a negative effect on the unemployment rate.

The results of research conducted by Annafi Indra Tama show that in the partial test ( $t$ test) only the local retribution, variable has a negative and significant effect on the unemployment rate while local taxes and capital expenditures have no effect.

From the description above, it can be reduced to the second hypothesis in this study, namely:

$H_{2}$ : Local charges have a negative effect on the unemployment rate.

Local taxes and retribution are one of the three components of the composition of PAD. It is hoped that the increase in local tax revenues and retribution, hereinafter referred to as taxes and retribution, is expected to be able to make a positive contribution to regional infrastructure development.[11] In addition to the provision of physical facilities, the proceeds from local taxes and retribution can also be used to carry out activities that increase creativity and attract public interest to participate, so it is hoped that these activities will be added with the availability of new public facilities, opening up job opportunities for a community will be created which in turn can reduce the unemployment rate in the district / city.

$H_{3}$ : Simultaneously local taxes and retribution have a negative effect on the unemployment rate.

Chang \&Ho's research in Abdul Rahman states that Regional Original Income (PAD) affects economic growth by looking at the results of the analysis of the elasticity of PAD on Gross Regional Domestic Income (PDRB).

Lin and Liu in Priyo state that development spending is a logical attempt by local governments to increase public trust in order to increase regional economic growth.[12] The study found a strong relationship between capital expenditure and the level of decentralization, which encourages and accelerates economic growth in the regions, thereby reducing the unemployment rate. So from this description, the fourth and fifth hypotheses can be derived as follows:

$H_{4}$ : Capital expenditure strengthens the negative effect of local taxes on the unemployment rate

$H_{5}$ : Capital expenditure strengthens the negative effect of regional retribution on the unemployment rate

\section{Research Methodology}

\subsection{Data Sources and Samples}

This study uses quantitative analysis techniques using ratio data which data collection with secondary data. The object of this research is the realization of local taxes and retribution and the capital expenditure budget and the unemployment rate in Madiun City during 2010 - 2019. The data is obtained from data published by the Central Statistics Agencyof Madiun City which is listed in the City of Madiun in Figures. 


\subsection{Data Collection Instruments}

In this study, the type of data collection instrument uses documentation techniques, in this case the researcher documents data from written objects such as magazines, books, regulations, and regional financial reports in the form of published digital data. The documentation technique is used because the data to be researched is available and documented by the Central Statistics Agency (BPS) of Madiun City and publicly published to the people in need. The measuring instrument used to measure the instrument is Regional Original Income.

\subsection{Method of collecting data}

The data used in this study were obtained in the form of finished data from the Central Statistics Agency (BPS) Madiun City, namely data on local taxes, retribution, capital expenditures and unemployment rates. Data is compiled in Annual data (Time series) from 2010 - 2019

\subsection{Research Data Testing}

\subsubsection{Data Normality Test}

The data normality test is carried out to determine whether the data is normally distributed or not. This test is performed using the One-Sample Kolmogrov-Smirnov Test (K-S) on the residual data. The data is said to be normally distributed if the significance value is $>0.05$. The data normality test was carried out for 3 equation models, namely the Multiple Linear Regression equation model (X1 and X2), the MRA Model for the Interaction of Tax Variables with Capital Expenditure $(\mathrm{X} 1 * \mathrm{M})$, and the MRA Model for the Interaction of Retribution Variable with Capital Expenditure (X2* M)

\subsubsection{Hypothesis test}

\section{a) Multiple Linear Regression}

In this analysis it will be known whether each independent variable has a positive or negative relationship and to predict the value of the dependent variable, if the value of the independent variable has increased or decreased. The multiple linear regression equation is as follows:

$Y^{\prime}=a+b 1 X 1+b 2 X 2+\varepsilon$

Where :

$\mathrm{Y}^{\prime} \quad$ : the Unemployment Rate

$\mathrm{X} 1 \quad$ : Tax

X2 : Retribution

a : Constants

b1, b2 : Regression coefficient

$\varepsilon \quad:$ the default error is assumed to be zero 


\section{b) Simultaneous Test (F Test)}

Simultaneous test is used to determine the effect of the independent variables Tax (X1) and Retribution (X2) together on the dependent variable the Unemployment Rate (Y). If the value of $\mathrm{F}$ count $>$ from $\mathrm{F}$ table is obtained, it can be concluded that simultaneously the Tax (X1) and Retribution (X2) have an effect on the Unemployment Rate (Y).

\section{c) Partial Test (t test)}

In order to know the effect partially or individually between the variables of Tax (X1), Retribution (X2), the Capital Expenditure (M), the interaction of the Tax Variable with Capital Expenditure $(\mathrm{X} 1 * \mathrm{M})$, and the Interaction of the Retribution with Capital Expenditure $(\mathrm{X} 2 * \mathrm{M})$. The Unemployment Rate $(\mathrm{Y})$ variable can be observed by looking at the t count value in the coefficient table, which is then compared to the $t$ table. If $t$ count $>t$ table then it is included in the rejection of H0 which means Tax (X1) Retribution (X2), Capital Expenditure (M), Interaction of Tax with Capital Expenditure $(\mathrm{X} 1 * \mathrm{M})$, and Interaction of Retribution with Capital Expenditure $(\mathrm{X} 2 * \mathrm{M})$ partially affects the dependent variable Unemployment Rate (Y)

\section{d) Interaction Test}

There are three ways to test regression with moderating variables .[13] that is: (1) Interaction test or Moderated Regression Analysis (MRA); (2) Test the difference between the absolute; and (3) Residual test. In this research, the test to be carried out is the interaction test or the Moderated Regression Analysis (MRA) test. MRA differs from subgroup analysis in that it uses an analytical approach that maintains sample integrity and provides a basis for controlling for the influence of moderating variables. To use MRA with three predictor variables (X1 X2 and $\mathrm{M}$ ), we must compare the three regression equations to determine the type of moderator variable.

The three equations are:

$$
\begin{aligned}
& \mathrm{Y}=\mathrm{a}+\mathrm{b} 1 \mathrm{X} 1+\mathrm{b} 2 \mathrm{X} 2+\varepsilon \\
& \mathrm{Y}=\mathrm{a}+\mathrm{b} 1 \mathrm{X} 1+\mathrm{b} 2 \mathrm{M}+\mathrm{b} 3 \mathrm{X} 1 * \mathrm{M}+\varepsilon \\
& \mathrm{Y}=\mathrm{a}+\mathrm{b} 1 \mathrm{X} 2+\mathrm{b} 2 \mathrm{M}+\mathrm{b} 3 \mathrm{X} 2 * \mathrm{M}+\varepsilon
\end{aligned}
$$

Where :

$\mathrm{Y}^{\prime} \quad$ : The Unemployment Rate

$\mathrm{X} 1 \quad:$ Tax

$\mathrm{X} 2 \quad$ : Retribution

M : Capital Expenditures

$\mathrm{X} 1 * \mathrm{M} \quad$ : Interaction of Tax with CapitalExpenditures

$\mathrm{X} 2 * \mathrm{M}$ : Interaction of Retributionwith Capital Expenditures

a : Constants

b1, b2, b3 : Regression coefficient 


\section{e) Determination Coefficient Test}

This study will test three of the determination coefficient namely the test for the Multiple Linear Regression model with Tax and Retribution (X1 and X2), the determination coefficient of the MRA model for the Interaction of Tax with Capital Expenditure $(\mathrm{X} 1 * \mathrm{M})$ and the determination coefficient of the MRA model for the Interaction of Retribution with Capital Expenditures $(\mathrm{X} 2 * \mathrm{M})$

\section{Results}

\subsection{Regional Original Revenue (PAD) of Madiun City}

In Madiun City Regional Regulation Number 60 of 2018 concerning the Elaboration of the 2019 Regional Budget (APBD) Article 1 states that the total revenue of Madiun City is IDR $1,099,350,535,600$, while the total expenditure is IDR $1,221,755,866,508$, - so that there is a budget deficit of IDR. 122,405,330,908. From the total amount of revenue obtained, the amount of original regional revenue which is the target of revenue is IDR. 206,488,824,600. From the target, the amount of PAD in 2019 can be exceeded and realized by IDR. $252,048,754,000$. The revenue achievement from PAD of Madiun City in 2018 was IDR. 230,847,977,000 from the set target of IDR. 192 billion. In 2017, the PAD target was set at IDR. 192 billion, while the realization was IDR. 230 billion.

From the realization of PAD that is obtained every year, it can be said that the Madiun City Government has a good achievement where the achievement of PAD realization always exceeds the set target. Likewise, this shows the ability of the city government to maximize regional revenue potential so that the ability to finance regional expenditure is also getting bigger. The realization of Madiun City's Original Regional Revenue in the last five years can be seen in the following table:

Table 1. Realization of Regional Original Revenue (PAD) of Madiun City 2015 - 2019 (in thousands of rupiah)

\begin{tabular}{cccccc}
\multicolumn{6}{c}{ Madiun City $2015-2019$ (in thousands of rupiah) } \\
\hline & \multicolumn{5}{c}{ Year } \\
PAD Resources & $\mathbf{2 0 1 5}$ & $\mathbf{2 0 1 6}$ & $\mathbf{2 0 1 7}$ & $\mathbf{2 0 1 8}$ & $\mathbf{2 0 1 9}$ \\
\hline Loical Tax & 58.947 .338 & 64.045 .559 & 75.224 .832 & 83.454 .704 & 91.077 .192 \\
$\begin{array}{c}\text { Retribution } \\
\text { Regional Owned }\end{array}$ & 16.537 .857 & 16.762 .538 & 18.407 .218 & 19.138 .961 & 20.301 .326 \\
$\begin{array}{c}\text { Enterprises } \\
\text { The other of }\end{array}$ & 11.143 .326 & 11.172 .032 & 13.320 .249 & 13.365 .403 & 14.641 .711 \\
legal PAD & 637.890 .739 & 81.255 .800 & 123.656 .418 & 114.888 .910 & 126.028 .525 \\
\hline Total of PAD & $\mathbf{7 2 4 . 5 1 9 . 2 8 0}$ & $\mathbf{1 7 3 . 2 3 5 . 9 3 0}$ & $\mathbf{2 3 0 . 6 0 8 . 7 1 7}$ & $\mathbf{2 3 0 . 8 4 7 . 9 7 7}$ & $\mathbf{2 5 2 . 0 4 8 . 7 5 4}$ \\
\hline
\end{tabular}

Source :Central Statistics Agency (BPS) ), Madiun Municipality in Figure, processed

\subsection{Madiun's Local Tax}

The realization of local tax revenue for 10 years from 2010 to 2019 can be seen in the following table: 
Table 2. Realization of Local Tax Revenue and Percentage of Total PAD Madiun City, 2010 - 2019 (in thousands of rupiah)

\begin{tabular}{cccccc}
\hline Year & $\begin{array}{c}\text { Local Tax } \\
\text { Realization }\end{array}$ & $\begin{array}{c}\text { Increase of Tax } \\
(\%)\end{array}$ & Total PAD & $\begin{array}{c}\text { Increase of } \\
\text { PAD (\%) }\end{array}$ & $\begin{array}{c}\text { Tax Realized } \\
\text { to PAD (\%) }\end{array}$ \\
\hline $\mathbf{2 0 1 0}$ & 12.744 .350 & - & 41.757 .000 & - & 30,52 \\
$\mathbf{2 0 1 1}$ & 23.200 .982 & 82,04 & 61.305 .077 & 46,81 & 37,84 \\
$\mathbf{2 0 1 2}$ & 29.323 .185 & 26,38 & 72.030 .951 & 17,49 & 40,70 \\
$\mathbf{2 0 1 3}$ & 34.432 .024 & 17,42 & 96.011 .481 & 33,29 & 35,86 \\
$\mathbf{2 0 1 4}$ & 54.173 .502 & 57,33 & 134.584 .344 & 40,17 & 40,25 \\
$\mathbf{2 0 1 5}$ & 58.947 .338 & 8,81 & 724.519 .280 & 438,33 & 8,13 \\
$\mathbf{2 0 1 6}$ & 64.045 .559 & 8,64 & 173.235 .930 & $-76,08$ & 36,97 \\
$\mathbf{2 0 1 7}$ & 75.224 .832 & 17,45 & 230.608 .717 & 33,11 & 32,62 \\
$\mathbf{2 0 1 8}$ & 83.454 .704 & 10,94 & 230.847 .977 & 0,10 & 36,15 \\
$\mathbf{2 0 1 9}$ & 91.077 .192 & 9,13 & 252.048 .754 & 9,18 & 36,13 \\
\hline
\end{tabular}

Source :Central Statistics Agency (BPS) ), Madiun Municipality in Figure, processed

From table 2 it can be seen that the realization of tax revenue in Madiun City increases every year. The biggest increase occurred in 2011 where tax revenue increased $82.04 \%$ from the previous year. In that year the Regional Tax was able to contribute $37.84 \%$ of the entire Regional Original Revenue of Madiun City. The lowest tax increase occurred in 2016, where the tax increase in that year only reached $8.64 \%$, however, tax was able to contribute to PAD in that year by $36.97 \%$. The largest tax contribution in PAD revenue occurred in 2012 where the tax contribution reached $40.7 \%$, even though the tax increase in that year only reached $26.3 \%$ which of course this figure is far below the increase in tax in the previous year. In general, it can be said that during the period 2010 - 2019 tax revenue always increased, with an average percentage increase of $23.8 \%$ each year

\subsection{Regional Retribution}

From table 3 it can be seen that the realization of retribution revenue in Madiun City is different when compared to tax revenue. From year to year, local taxes always increase the amount of revenue, while retributionfluctuate. There has been a decrease in the number of retribution receipts twice in a period of 10 years, namely in 2013 and 2015, where in 2013 there was a decrease in retribution receipts by $43.7 \%$ from 2012, while in 2015 there was a decrease in revenues by $14.9 \%$ from 2014. The largest increase in revenue occurred in 2011 where retribution receipts increased $37.5 \%$ from the previous year. In that year the Regional Tax was able to contribute $43.15 \%$ of the entire Regional Original Revenue of Madiun City. As with tax revenue in 2016, the lowest increase in user fees also occurred in that year, where the increase in retribution only reached $1.35 \%$. In that year, retribution was only able to contribute $9.67 \%$ of PAD. The largest contribution of retribution in PAD revenue occurred in 2010 where out of the total revenue of PAD was IDR. 41,757,000,000, - 46.6\% of which is income from retribution, which is IDR. 19,233,818,000, - Retribution receipts in Madiun City have increased in the last four years with an average increase of $5.30 \%$. 
Table 3. Realization of Local Retribution Revenue and Percentage of Total PAD Madiun City, 2010 - 2019 (in thousands of rupiah)

\begin{tabular}{rrrrrr}
\hline Year & $\begin{array}{l}\text { Realization of } \\
\text { Retribution }\end{array}$ & $\begin{array}{l}\text { Increase of } \\
\text { Retribution (\%) }\end{array}$ & Total PAD & $\begin{array}{l}\text { Increase } \\
\text { of PAD } \\
(\%)\end{array}$ & $\begin{array}{l}\text { Retribution } \\
\text { Realization } \\
\text { to PAD (\%) }\end{array}$ \\
\hline 2010 & 19.233 .818 & - & 41.757 .000 & - & 46,06 \\
2011 & 26.456 .644 & 37,55 & 61.305 .077 & 46,81 & 43,15 \\
2012 & 30.451 .296 & 15,09 & 72.030 .951 & 17,49 & 42,27 \\
2013 & 17.116 .761 & $-43,78$ & 96.011 .481 & 33,29 & 17,82 \\
2014 & 19.450 .076 & 13,63 & 134.584 .344 & 40,17 & 14,45 \\
2015 & 16.537 .857 & $-14,97$ & 724.519 .280 & 438,33 & 2,28 \\
2016 & 16.762 .538 & 1,35 & 173.235 .930 & $-76,08$ & 9,67 \\
2017 & 18.407 .218 & 9,81 & 230.608 .717 & 33,11 & 7,98 \\
2018 & 19.138 .961 & 3,97 & 230.847 .977 & 0,10 & 8,29 \\
2019 & 20.301 .326 & 6,07 & 252.048 .754 & 9,18 & 8,05 \\
\hline
\end{tabular}

Source :Central Statistics Agency (BPS) ), Madiun Municipality in Figure, processed

\subsection{Capital Expenditure}

Table 4. Realization of Capital Expenditure and Percentage of Total Local Government Exp in 2010 - 2019 (in thousands of rupiah)

\begin{tabular}{lccccr} 
Year & $\begin{array}{c}\text { Realixation } \\
\text { of Capital } \\
\text { Expenditure }\end{array}$ & $\begin{array}{c}\text { Increase } \\
(\%)\end{array}$ & $\begin{array}{c}\text { Total of Local } \\
\text { Governmnet } \\
\text { Expenditure }\end{array}$ & $\begin{array}{c}\text { Increase } \\
(\%)\end{array}$ & $\begin{array}{c}\text { Realizayion of Cap } \\
\text { Exp to Local } \\
\text { GovExp (\%) }\end{array}$ \\
\hline 2010 & 123.209 .748 & & & & 24,33 \\
2011 & 95.674 .954 & $-22,34$ & 526.846 .073 & 4,06 & 18,15 \\
2012 & 137.365 .906 & 43,57 & 610.542 .092 & 15,88 & 22,49 \\
2013 & 180.111 .321 & 31,11 & 775.087 .202 & 26,95 & 23,23 \\
2014 & 201.296 .642 & 11,76 & 1.054 .769 .960 & 36,08 & 20,79 \\
2015 & 182.413 .227 & $-9,38$ & 877.219 .888 & $-16,83$ & 23.88 \\
2016 & 246.394 .705 & 35,07 & 1.031 .564 .193 & 17.59 & 26.80 \\
2017 & 255.977 .976 & 3,88 & 954.991 .703 & -7.42 & 26.99 \\
2018 & 259.087 .612 & 1,21 & 1.036 .658 .831 & 8.55 & \\
2019 & 307.800 .742 & 18,80 & 1.148 .496 .711 & 10.78 & 26.80 \\
\hline
\end{tabular}

Source :Central Statistics Agency (BPS) ), Madiun Municipality in Figure, processed

From table 4, it can be seen that the realization of capital expenditure in Madiun City has fluctuated. Capital expenditure has decreased twice, namely in 2011 and 2015. In 2011 the value of capital expenditure decreased $22.3 \%$ from the previous year, where in that year the realization of capital expenditure only reached IDR 95,674,954,000 when compared to the previous year. previously which reached IDR. 123,209,748,000, -. Meanwhile in 2015 the value of capital expenditure reached IDR. 182,413,227,000 lower than that in 2014 which reached IDR. 201,296,642,000, - or decreased by $9.38 \%$.

The largest increase in capital expenditure occurred in 2012 where capital expenditure increased by $43.57 \%$ from the previous year. This is in line with the increase in regional spending which also increased by $15.88 \%$ from the previous year. In 2018 there was the smallest increase in capital expenditure, where capital expenditure in that year only increased by $1.21 \%$, while regional spending increased by $8.55 \%$. During the 10 -year period from 2010 - 2019 capital expenditure always fluctuates, as well as Regional Expenditures. Decrease in 
regional spending occurred in 2015 and 2017. In 2015, in addition to a decrease in regional spending, capital expenditure also decreased from the previous year, whereas in 2017 , although there was a decrease in regional spending by $7.42 \%$, capital expenditure was still an increase of $3.88 \%$ from the previous year.

\subsection{Open Unemployment Rate}

Based on data from the Central Statistics Agency (BPS) of Madiun City, as of August 2019 the unemployment rate in Madiun City increased to 3,776 people. This unemployment rate increased by around $8.41 \%$ compared to the previous year. In 2018 the number of unemployed people in Madiun City was 3,483 people. Meanwhile, the Madiun City Open Unemployment Rate (TPT) in August 2019 increased to 4.01\% compared to 2018 of 3.85\% or an increase of $0.16 \%$. The following table presents data on the number of unemployed people in Madiun City for 10 years from 2010 - 2019.

\begin{tabular}{ccccc}
\multicolumn{5}{c}{ Table 5. Total Unemployment and Open Unemployment Rate In Madiun City, 2010 - 2019 } \\
\hline Year & $\begin{array}{c}\text { Total } \\
\text { Unemployment }\end{array}$ & $\begin{array}{c}\text { Increase / } \\
\text { Decrease }\end{array}$ & $\begin{array}{c}\text { Percentage } \\
(\%)\end{array}$ & $\begin{array}{c}\text { Open Unemploymnet } \\
\text { Rate (TPT) }\end{array}$ \\
\hline 2010 & 8.415 & - & - & $7,30 \%$ \\
2011 & 4.552 & -3.863 & $-45,90$ & $6,82 \%$ \\
2012 & 5.622 & 1.070 & 23,50 & $5,74 \%$ \\
2013 & 5.948 & 326 & 5,79 & $5,30 \%$ \\
2014 & 6.005 & 57 & 0,95 & $5,80 \%$ \\
2015 & 4.629 & -1.376 & $-22,91$ & $5.10 \%$ \\
2016 & 5.715 & 1.086 & 23,46 & $5.10 \%$ \\
2017 & 4.020 & -1.695 & $-29,65$ & $4.26 \%$ \\
2018 & 3.483 & -537 & $-13,35$ & $3.85 \%$ \\
2019 & 3.776 & 293 & 8,41 & $4.01 \%$ \\
\hline Source :Central Statistics Agency (BPS) ), Madiun Municipality in Figure, processed
\end{tabular}

In table 4.5 it can be seen that the best conditions occurred in 2011, where the largest decrease in unemployment occurred. In that year there was a decrease in the number of unemployed by 3,863 people, where the number of unemployed in the previous year was 8,415 down to 4,552 or down 45.9\%. The decline occurred again in 2015, 2017 and in 2018 . Of the three periods, the largest decrease occurred in 2017, where the number of unemployed fell by 1,695 people. The number of unemployed people from the original 5,715 people decreased to 4,020 people or decreased by $29.65 \%$. During the period 2010 - 2019 the unemployment rate in Madiun City fluctuated. The decrease in the unemployment rate per year was $27.95 \%$ on average, while the increase in the unemployment rate per year reached $12.57 \%$ on average

\subsection{Data Normality Test Results}

Table 6 below shows that the Asymp. Sig. (2-tailed) each variable, namely Tax (X1) is 0.995, Variable Retribution (X2) is 0.967, Capital Expenditure (M) variable is 0.874, Interaction of Tax with Capital Expenditure $(\mathrm{X} 1 * \mathrm{M})$ is 1 , Interaction of Retribution with Capital Expenditure $(\mathrm{X} 2 * \mathrm{M})$ is 0.996 and the Unemployment Rate $(\mathrm{Y})$ is 0.946 . Because all the significance values of the variables in the Kolmogorov Smirnov test are greater than 0.05, 
it is not significant and it can be stated that the data is normally distributed and the regression model fulfills the assumption of normality.

Table 6. Output SPSS for Data Normality Test One-Sample Kolmogorov-Smirnov Test

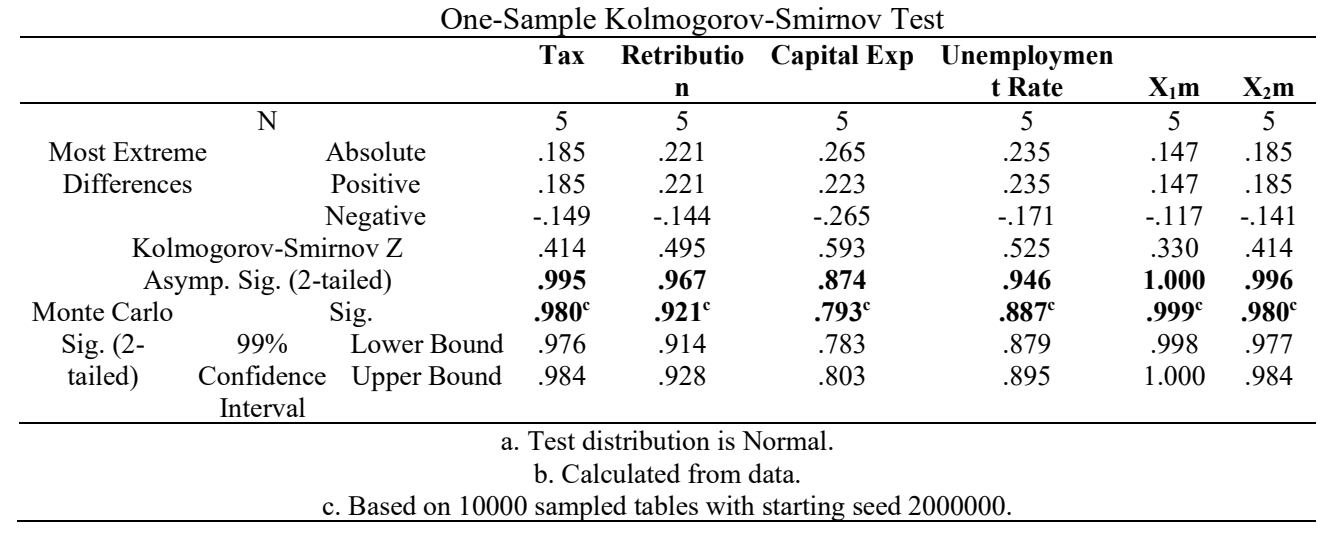

\subsection{Multiple Linear Regression Model Test Results}

Regression Results of Tax Variables (X1) and Retribution (X2) Against Unemployment Rate (Y)

Table 7. Output SPSS for Multiple Linear Regression Test

\section{Coefficients $^{\mathrm{a}}$}

\begin{tabular}{|c|c|c|c|c|c|c|}
\hline & \multirow[t]{2}{*}{ Model } & \multicolumn{2}{|c|}{$\begin{array}{l}\text { Unstandardized } \\
\text { Coefficients }\end{array}$} & \multirow{2}{*}{$\begin{array}{c}\begin{array}{c}\text { Standardized } \\
\text { Coefficients }\end{array} \\
\text { Beta }\end{array}$} & \multirow[t]{2}{*}{$\mathbf{t}$} & \multirow[t]{2}{*}{ Sig. } \\
\hline & & B & $\begin{array}{c}\text { Std. } \\
\text { Error }\end{array}$ & & & \\
\hline \multirow[t]{3}{*}{1} & (Constant) & 10643.659 & 1863.525 & & 5.712 & .001 \\
\hline & TAX & $-5.059 \mathrm{E}-005$ & .000 & -.929 & -4.134 & .004 \\
\hline & $\begin{array}{l}\text { RETRIBU } \\
\text { TION }\end{array}$ & .000 & .000 & -.421 & -1.874 & .103 \\
\hline
\end{tabular}

a. Dependent Variable: UNEMPLOYMENT RATE

From the table of results, a multiple linear regression equation can be formed as follows: $\mathrm{Y}^{\prime}=10,643,659-0,929 \mathrm{X} 1-0,421 \mathrm{X} 2$ or

Unemployment rate $=10,643,659-0,929$ Tax - 0,421 Retribution

Information :

a) The constant a value of $10,643,659$ indicates that if the Tax variable (X1) and the Retribution Variable (X2) are considered constant or zero, then the Unemployment Rate (Y) is $10,643,659$ units.

b) The regression coefficient value $\mathrm{X} 1$ is -0.929 , indicating that if the retribution variable (X2) is considered constant, then every addition of 1 Tax unit will reduce the Unemployment Rate (Y) by 0.929 units.

c) The regression coefficient value $\mathrm{X} 2$ is -0.421 shows that if the Tax variable (X1) is considered constant, then every addition of 1 unit of Retribution (X2) will reduce the Unemployment Rate (Y) by -0.421 units. 


\subsection{MRA Model Test Results for Tax Variables (X1), Capital Expenditures (M) and Interaction of Tax with Capital Expenditure $(\mathrm{X} 1 * \mathrm{M})$}

From the table below, an MRA regression equation can be formed as follows:

$\mathrm{Y}=3.693,272-1,739 \mathrm{X}_{1}+1,931 \mathrm{M}-0,868 \mathrm{X}_{1} \mathrm{M}$

Table 8. Output SPSS for MRA Model Test on Tax Variables (X1), Capital Expenditures $(\mathrm{M})$ and Interaction of Tax with Capital Expenditure $(\mathrm{X} 1 * \mathrm{M})$

\begin{tabular}{|c|c|c|c|c|c|c|}
\hline \multirow{2}{*}{\multicolumn{2}{|c|}{ Model }} & \multicolumn{2}{|c|}{$\begin{array}{l}\text { Unstandardized } \\
\text { Coefficients }\end{array}$} & \multirow{2}{*}{$\begin{array}{l}\begin{array}{l}\text { Standardized } \\
\text { Coefficients }\end{array} \\
\text { Beta }\end{array}$} & & \multirow[t]{2}{*}{ Sig. } \\
\hline & & $\overline{\mathbf{B}}$ & $\begin{array}{l}\text { Std. } \\
\text { Error }\end{array}$ & & & \\
\hline \multirow[t]{4}{*}{1} & (Constant) & 3693.272 & 1967.155 & & 1.877 & .110 \\
\hline & TAX & $-9.471 \mathrm{E}-005$ & .000 & -1.739 & -2.088 & .082 \\
\hline & $\begin{array}{l}\text { CAPITAL } \\
\text { EXP }\end{array}$ & 4.127E-005 & .000 & 1.931 & 2.559 & .043 \\
\hline & INTERX1M & $-1.412 \mathrm{E}-013$ & .000 & -.868 & -.793 & .458 \\
\hline
\end{tabular}

Information :

a) The constant value $\mathrm{a}=3.693,272$ indicates that if the Tax (X1) and Capital Expenditure (M) variable and the Interaction of Tax with Capital Expenditure (X1*M)variable are considered constant or zero, then the Unemployment Rate (Y) is 3.693,272 unit.

b) The regression coefficient value of $\mathrm{X} 1$ is -1.739 , indicating that if the Capital Expenditure variable $(\mathrm{M})$ and the Interaction of Tax with Capital Expenditure $(\mathrm{X} 1 * \mathrm{M})$ are considered constant or zero, then each additional 1 unit of Tax will reduce the Unemployment Rate (Y) by 1.739 units.

c) The regression coefficient value $\mathrm{M}$ is 1.931 , which indicates that if the Tax variable (X1) and the Interaction of Tax with Capital Expenditure $(\mathrm{X} 1 * \mathrm{M})$ are considered constant, then every addition of 1 unit of Capital Expenditure (M) will increase the Unemployment Rate (Y) by 1, 931 units.

d) The regression coefficient value of the $\mathrm{X} 1 * \mathrm{M}$ variable is -0.868 , indicating that if the Tax (X1) and Capital Expenditure (M) variables are considered constant or zero, then each addition of 1 unit of the $\mathrm{X} 1 * \mathrm{M}$ will reduce the Unemployment Rate(Y) by 0.868 unit.

4.9 MRA Model Test Results Variable Retribution (X2), Capital Expenditure (M) and Interaction of Retribution with Capital Expenditure (X2*M)

Table 9. Output SPSS for MRA Model Test on Retribution Variables (X2), Capital Expenditures (M) and Interaction of Retribution with Capital Expenditure (X2*M)

\begin{tabular}{lcccccc}
\hline \multirow{1}{*}{ Model } & \multicolumn{2}{c}{$\begin{array}{c}\text { Unstandardized } \\
\text { Coefficients }\end{array}$} & \multicolumn{2}{c}{$\begin{array}{c}\text { Standardized } \\
\text { Coefficients }\end{array}$} & t & Sig. \\
\cline { 2 - 5 } & B & Std. Error & Beta & & \\
\hline 1 (Constant) & 24075.688 & 10235.751 & & 2.352 & .057 \\
RETRIBUTIO & -.001 & .000 & -2.280 & -1.562 & .169 \\
N & & & & & \\
CAP EXP & $-9.973 E-005$ & .000 & -4.666 & -1.555 & .171 \\
INTERX2M & $4.070 \mathrm{E}-012$ & .000 & 3.370 & 1.302 & .241 \\
\hline
\end{tabular}


From the table above, an MRA regression equation can be formed as follows:

$\mathrm{Y}=24.075,688-2,280 \mathrm{X}_{2}-4,666 \mathrm{M}+3,370 \mathrm{X}_{2} \mathrm{M}$

Information :

a) The constant value a is $24,075,688$ indicating that if the Retribution (X2) and Capital Expenditure (M) variable and the Interaction of Retribution with Capital Expenditure variable $(\mathrm{X} 2 * \mathrm{M})$ are considered constant or zero, then the Unemployment Rate $(\mathrm{Y})$ is 24,075,688 units. .

b) The regression coefficient value of $\mathrm{X} 2$ is $-2,280$, indicating that if the Capital Expenditure variable $(\mathrm{M})$ and the Interaction of Retribution with Capital Expenditure $(\mathrm{X} 2 * \mathrm{M})$ are considered constant or zero, then every addition of 1 unit of Retribution will reduce the Unemployment Rate (Y) by 2,280 units .

c) The regression coefficient value of $M$ is -4.666 , which indicates that if the Charges variable (X2) and the Interaction of Retribution with Capital Expenditure variable $(\mathrm{X} 2 * \mathrm{M})$ are considered constant, then every addition of 1 unit of Capital Expenditure (M) will reduce the Unemployment Rate (Y) by 4.666 units.

d) The regression coefficient value of the $\mathrm{X} 2 * \mathrm{M}$ variable is 3,370 indicating that if the Retribution variable (X2) and the Capital Expenditure variable (M) are considered constant or zero, then every addition of 1 unit of the $\mathrm{X} 2 * \mathrm{M}$ Variable will increase the Unemployment Rate (Y) by 3,370 units .

\subsection{Partial Test (t test)}

The t value of Tax Variable (X1) and Retribution (X2)

Table 10. Output SPSS for $\mathrm{t}$ Test on Multiple Linear Regression

\begin{tabular}{|c|c|c|c|c|c|c|}
\hline & \multirow[t]{2}{*}{ Model } & \multicolumn{2}{|c|}{$\begin{array}{l}\text { Unstandardized } \\
\text { Coefficients }\end{array}$} & \multirow{2}{*}{$\begin{array}{c}\text { Standardized } \\
\text { Coefficients } \\
\text { Beta }\end{array}$} & \multirow[t]{2}{*}{$\mathbf{t}$} & \multirow[t]{2}{*}{ Sig. } \\
\hline & & B & $\begin{array}{c}\text { Std. } \\
\text { Error }\end{array}$ & & & \\
\hline 1 & (Constant) & 10643.659 & $\begin{array}{c}1863.52 \\
5\end{array}$ & & 5.712 & .001 \\
\hline & TAX & $-5.059 \mathrm{E}-005$ & .000 & -.929 & -4.134 & .004 \\
\hline & $\begin{array}{l}\text { RETRIB } \\
\text { UTION }\end{array}$ & .000 & .000 & -.421 & -1.874 & .103 \\
\hline
\end{tabular}

a. Dependent Variable: UNEMPLOYMENT RATE

\section{a) t Test Results on The Tax Variable (X1)}

Based on the results of the partial test for the Tax Variable (X1), the t-count value is -4.134 with a significance value of 0.004 . The value of -ttable is $-2,306$. Because $-t$ count $=-4,134<-$ ttabel $=-2,306$ and a significance value of $0.004<0.05$, it can be concluded that the Tax Variable (X1) has a significant effect on the Unemployment Rate (Y). The value of the beta coefficient $(\beta)$ of the Tax variable (X1) is -0.929 which is negative (-) in that this figure indicates an opposite relationship. 


\section{b. $t$ Test Results on The Retribution Variable (X2)}

Based on the results of the partial test for Retribution (X2), the calculated value is $-1,874$ with a significance value of 0.103 . The value of -ttable is $-2,306$. Because $-t$ count $=-1,874>-$ ttable $=-2,306$ and a significance value is $0.103>0.05$, it can be concluded that the Retribution Variable (X2) has no significant effect on the Unemployment Rate (Y). The value of the beta coefficient $(\beta)$ of the retribution variable $(\mathrm{X} 2)$ is -0.421 which is negative $(-)$ in that numberindicates a relationship in the opposite direction .

\subsection{Simultaneous Test Results (F Test)}

Based on ouput table of the simultaneous test, it was obtained that the Fcount value was 8.554 with a significance value is 0.013 . The value of Ftable was obtained at 4.74 . Because Fcount $=8,554>$ Ftable $=4.74$ and a significance value is $0.013<0.05$, it can be concluded that the Tax Variable (X1) and the Retribution Variable (X2) simultaneously have a significant effect on the Unemployment Rate (Y).

Table 11. Output SPPS for F Test on Multiple Linear Regression

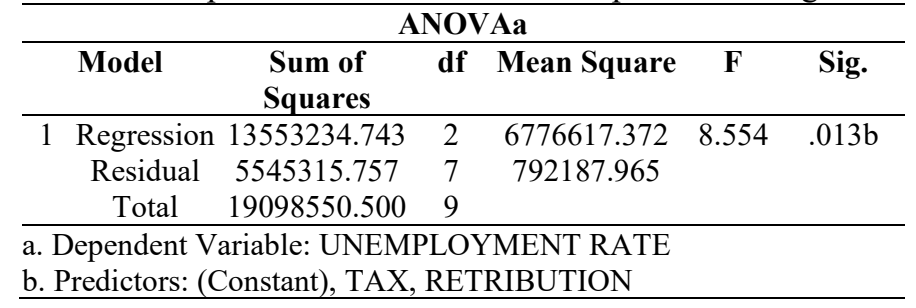

\subsection{2 t Test Results of Moderated Regression Analysis with Tax Variables (X1), Capital Expenditure (M) and Interaction of Tax with Capital Expenditure $(\mathrm{X} 1 * \mathrm{M})$}

The $\mathrm{t}$ test results are as shown in the table below:

Table 12. Output SPSS for $t$ Test on MRA with Tax Variables (X1), Capital Expenditure $(\mathrm{M})$ and Interaction of Tax with Capital Expenditure $(\mathrm{X} 1 * \mathrm{M})$

\begin{tabular}{|c|c|c|c|c|c|}
\hline \multicolumn{6}{|c|}{ Coefficientsa } \\
\hline \multirow[t]{2}{*}{ Model } & \multicolumn{2}{|c|}{$\begin{array}{l}\text { Unstandardized } \\
\text { Coefficients }\end{array}$} & \multirow{2}{*}{$\begin{array}{c}\begin{array}{c}\text { Standardized } \\
\text { Coefficients }\end{array} \\
\text { Beta }\end{array}$} & \multirow[t]{2}{*}{ t } & \multirow[t]{2}{*}{ Sig. } \\
\hline & B & Std. Error & & & \\
\hline$\overline{1 \text { (Constant) }}$ & 3693.272 & 1967.155 & & 1.877 & .110 \\
\hline TAX & $-9.471 \mathrm{E}-005$ & .000 & -1.739 & -2.088 & .082 \\
\hline CAPITAL EXP & 4.127E-005 & .000 & 1.931 & 2.559 & .043 \\
\hline INTERX1M & $-1.412 \mathrm{E}-013$ & .000 & -.868 & -.793 & .458 \\
\hline \multicolumn{6}{|c|}{ a. Dependent Variable: UNEMPLOYMENT RATE } \\
\hline
\end{tabular}

\section{a) t Test Results on The Tax Variable (X1)}

Based on the results of the partial test for the Tax Variable (X1), the t-count value is -2.088 with a significance value is 0.082 . The -table value is obtained at -2.364 Because $-t$ count $=-$ $2.088>-\mathrm{t}$ table $=-2.364$ and a significance value of $0.082>0.05$, it can be concluded that the Tax Variable (X1) has no significant effect on the Unemployment Rate (Y). The value of the 
beta coefficient ( $\beta$ ) of the Tax variable (X1) is -1.739 which is negative (-) in that this number indicates a relationship in the opposite direction.

\section{b) t Test Results on Capital Expenditures Variable (M)}

Based on the results of the partial test for the variable capital expenditure (M), the tcount value is 2.559 with a significance value is 0.043 . The t-table value was obtained at 2.364 . Because tcount $=2.559>$ ttable $=2.364$ and a significance value of $0.043<0.05$, it can be concluded that the Capital Expenditure Variable (M) has a significant effect on the Unemployment Rate $(\mathrm{Y})$. The value of the beta coefficient $(\beta)$ of the Capital Expenditure variable $(\mathrm{M})$ is 1.931 which is positive $(+)$ in that this number indicates a unidirectional relationship.

\section{c) t Test Result on Interaction of Tax with Capital Expenditure $(\mathrm{X} 1 * \mathrm{M})$}

Based on the results of the partial test for the Interaction of Tax with Capital Expenditure $(\mathrm{X} 1 * \mathrm{M})$, the tcount value is -0.793 with a significance value is 0.458 . The value of -ttable is 2,364 . Because $-t$ count $=-0.793>-$ ttable $=-2.364$ and a significance value is $0.458>0.05$, it can be concluded that the Interaction of Taxwith Capital Expenditures $(\mathrm{X} 1 * \mathrm{M})$ does not significantly affect the Unemployment Rate $(\mathrm{Y})$. The value of the beta coefficient $(\beta)$ of variable $\mathrm{X} 1 * \mathrm{M}$ is -0.868 which is negative (-) in that this number indicates a relationship in the opposite direction. Based on the results of the t-test for the Tax Variable (X1), Capital Expenditure (M) and Interactionof Tax with Capital Expenditure $(\mathrm{X} 1 * \mathrm{M})$, it can be concluded that the Capital Expenditure variable $(M)$ does not moderate the relationship between the Tax variable (XI) and the Unemployment Rate. In other words, in this equation model the capital expenditure variable is not a moderating variable.

4.13 $t$ Test Results of Moderated Regression Analysis with Retribution (X2), Capital Expenditure (M) and Interaction of Retribution with Capital Expenditure (X2*M)

The $t$ test results are as shown in the table below:

Table 13. Output SPSS for $t$ Test on MRA with Retribution (X2), Capital Expenditure (M) and Interaction of Retribution with Capital Expenditure (X2*M)

\begin{tabular}{|c|c|c|c|c|c|c|}
\hline \multicolumn{7}{|c|}{ Coefficients $^{\mathbf{a}}$} \\
\hline & \multirow[t]{2}{*}{ Model } & \multicolumn{2}{|c|}{$\begin{array}{l}\text { Unstandardized } \\
\text { Coefficients } \\
\end{array}$} & \multirow{2}{*}{$\begin{array}{c}\begin{array}{c}\text { Standardized } \\
\text { Coefficients }\end{array} \\
\text { Beta }\end{array}$} & \multirow[t]{2}{*}{$\mathbf{T}$} & \multirow[t]{2}{*}{ Sig. } \\
\hline & & B & $\begin{array}{l}\text { Std. } \\
\text { Error }\end{array}$ & & & \\
\hline 1 & (Constant) & $\begin{array}{c}24075.68 \\
8\end{array}$ & $\begin{array}{c}10235.75 \\
1\end{array}$ & & 2.352 & $\begin{array}{c}.05 \\
7\end{array}$ \\
\hline & $\begin{array}{l}\text { RETRIBU } \\
\text { TION }\end{array}$ & -.001 & .000 & -2.280 & -1.562 & $\begin{array}{l}.16 \\
9\end{array}$ \\
\hline & $\begin{array}{l}\text { CAPITAL } \\
\text { EXP }\end{array}$ & $\begin{array}{c}-9.973 \mathrm{E}- \\
005\end{array}$ & .000 & -4.666 & -1.555 & $\begin{array}{c}.17 \\
1\end{array}$ \\
\hline & $\begin{array}{l}\text { INTERX2 } \\
\text { M }\end{array}$ & $\begin{array}{l}4.070 \mathrm{E}- \\
012\end{array}$ & .000 & 3.370 & 1.302 & $\begin{array}{c}.24 \\
1\end{array}$ \\
\hline
\end{tabular}




\section{a) t Test Results on Retribution Variable (X2)}

Based on the results of the partial test for the Retributionvariable (X2), the value-tcount is 1.562 with a significance value is 0.169 . The $-\mathrm{t}$ table value is obtained at -2.364 . Because $-\mathrm{t}$ count $=-1.562>-$ ttable $=-2.364$ and the significance value is $0.169>0.05$, it can be concluded that the Retribution Variable (X2) does not significantly affect the Unemployment Rate (Y). The value of the beta coefficient $(\beta)$ of the retribution variable (X2) is $-2,280$ which is negative (-) in that this number indicates an opposite relationship.

\section{b) t Test Results on Capital Expenditures Variable (M)}

Based on the results of the partial test for the variable capital expenditure $(\mathrm{M})$, the valuetcount is -1.555 with a significance value is 0.171 . The $-t$ table value is obtained at -2.364 . Because $-t$ count $=-1.555>-$ ttable $=-2.364$ and a significance value is $0.171>0.05$, it can be concluded that the Capital Expenditure Variable (M) does not significantly affect the Unemployment Rate (Y). The value of the beta coefficient $(\beta)$ of the Capital Expenditure variable (M) is -4.666 which is negative (-) in that this number indicates a relationship in the opposite direction.

\section{c) t Test Results on the Interaction of Retribution with Capital Expenditures (X2*M)}

Based on the results of the partial test for the Interaction of RetributionVariable withCapital Expenditure $(\mathrm{X} 2 * \mathrm{M})$, the tcount value is 1.302 with a significance value is 0.241 . The $\mathrm{t}$ table value was obtained at 2.364. Because tcount $=1.302<$ ttable $=2.364$ and a significance value of $0.241>0.05$, it can be concluded that the Interaction of RetributionVariable with Capital Expenditures $(\mathrm{X} 2 * \mathrm{M})$ has no significant effect onthe Unemployment Rate (Y). The value of the beta coefficient $(\beta)$ of variable $\mathrm{X} 2 * \mathrm{M}$ is 3,370 which is positive $(+)$ in that this number indicates a unidirectional relationship. Based on the results of the t-test for the variable retribution (X2), capital expenditures $(\mathrm{M})$ and the Interaction ofRetribution with Capital Expenditures $(\mathrm{X} 2 * \mathrm{M})$, it can be concluded that the variable capital expenditures $(\mathrm{M})$ does not moderate the relationship between retribution (X2) and the unemployment rate. In other words, in this equation model the Capital Expenditure variable is not a moderating variable.

\subsection{The Result of Determination Coefficient $\left(R^{2}\right)$ Multiple Linear Regression}

The test results are shown in the output table below:

Table 14. Output SPSS for Determination Coefficient $\left(\mathrm{R}^{2}\right)$ on Multiple Linear Regression

\begin{tabular}{ccccc}
\hline \multicolumn{4}{c}{ Model Summary } \\
\hline Model & R & R Square & $\begin{array}{c}\text { Adjusted R } \\
\text { Square }\end{array}$ & $\begin{array}{c}\text { Std. Error of } \\
\text { the Estimate }\end{array}$ \\
\hline 1 & $.842^{\text {a }}$ & .710 & .627 & 890.049 \\
\hline a. Predictors: (Constant), RETRIBUSI, PAJAK \\
\hline
\end{tabular}

Based on table above, the value of Adjusted $R$ Square $\left(\mathrm{R}^{2}\right)$ is 0.627 . This means that the Tax variable (X1) and Retribution (X2) can explain the variation of the Unemployment Rate 
of $62.7 \%$. While the remaining $36.3 \%$ is explained by other variables not examined in this study

\subsection{Test Results of the Determination Coefficient $\left(R^{2}\right)$ MRA Regression for Tax Variables (X1), Capital Expenditure (M) and Interactionof Tax with Capital Expenditure (X1*M)}

The test results are shown in the output table below:

Table 15. Output SPSS for Determination Coefficient $\left(R^{2}\right)$ of MRA on Tax Variables (X1), Capital Expenditure (M) and Interaction of Tax with Capital Expenditure $(\mathrm{X} 1 * \mathrm{M})$

\begin{tabular}{lcccc}
\hline \multicolumn{5}{c}{ Model Summary } \\
\hline Model & R & R Square & $\begin{array}{c}\text { Adjusted R } \\
\text { Square }\end{array}$ & $\begin{array}{c}\text { Std. Error of the } \\
\text { Estimate }\end{array}$ \\
\hline 1 & $.901^{\mathrm{a}}$ & .811 & .717 & 775.316 \\
\hline $\begin{array}{l}\text { a. Predictors: (Constant), INTERX1M, BELANJA MODAL, } \\
\text { PAJAK }\end{array}$
\end{tabular}

Based on the table above, the value of Adjusted $R$ Square $\left(R^{2}\right)$ is 0.717 . This means that the Tax variable (X1) Capital Expenditure (M) and Interaction of Tax with Capital Expenditure $(\mathrm{X} 1 * \mathrm{M})$ can explain the variation in the dependent variable Unemployment Rate (Y) of $71.7 \%$. While the remaining $28.3 \%$ is explained by other variables not examined in this study

4.16 Test Results of the Determination Coefficient $\left(R^{2}\right)$ of MRA Regression Variable Retribution X2, Capital Expenditures (M) and Interaction of Retribution with Capital Expenditures $(\mathrm{X} 2 * \mathrm{M})$

The test results are shown in the output table below:

Table 16. Output SPSS for Determination Coefficient $\left(\mathrm{R}^{2}\right)$ of MRA on Variable Retribution X2, Capital Expenditures $(\mathrm{M})$ and Interaction of Retribution with Capital Expenditures $(\mathrm{X} 2 * \mathrm{M})$

\begin{tabular}{lcccc}
\multicolumn{5}{c}{ Model Summary } \\
\hline Model & R & R Square & $\begin{array}{c}\text { Adjusted } \\
\text { R Square }\end{array}$ & $\begin{array}{c}\text { Std. Error of the } \\
\text { Estimate }\end{array}$ \\
\hline 1 & $.758^{\text {a }}$ & .575 & .362 & 1163.509 \\
\hline a. Predictors: (Constant), INTERX2M, RETRIBUTION, \\
CAPITAL EXPENDITURE \\
\hline
\end{tabular}

Based on the table above, the Adjusted R Square $\left(\mathrm{R}^{2}\right)$ value is 0.362 . This means that the variable Retribution (X2) Capital Expenditure (M) and Interaction of Retribution with Capital Expenditure $(\mathrm{X} 2 * \mathrm{M})$ can explain the variation of the dependent variable Unemployment Rate (Y) of $36.2 \%$. While the remaining $63.8 \%$ is explained by other variables not examined in this study

\section{Conclutions}

From the results of the regression test on the data, it can be concluded as follows: 
a) Tax variable (X1) partially has a significant effect on the unemployment rate. This effect is negative, so that any increase in tax revenue will reduce the unemployment rate, so the first hypothesis (H1) is proven

b) The Retribution variable (X2) has no significant effect on the Unemployment Rate (Y), thus the second hypothesis $(\mathrm{H} 2)$ proposed is not proven

c) Tax variables (X1) and Retribution (X2) simultaneously affect the Unemployment Rate (Y) thus the third hypothesis (H3) proposed is proven

d) Capital Expenditure (M) does not moderate the relationship between the Tax variable (X1) and the Unemployment Rate (Y), thus the fourth hypothesis (H4) is not proven

e) Capital Expenditures (M) do not moderate the relationship between the Retribution(X2) variable and the Unemployment Rate (Y), thus the proposed fifth hypothesis (H5) is not proven.

\section{References}

[1] Mamesah, D, J 1995 Regional Financial Administration System (Jakarta: PT. GramediaPustakaUtama)

[2] Mardiasmo 2004 Autonomy and Regional Financial Management (Yogyakarta: Andi)

[3] Oates W Fiscal Decentralization And Economic Development Natl. Tax J. Vol. 46 237-43.

[4] Blanchard O 2000 The Economics Of Unemployment. Shocks, Institutions, And Interactions Lionel Robins Lect.

[5] Halim A 2007 Akuntansi Sektor Publik: Akuntansi Keuangan Daerah. (Jakarta: Salemba Empat)

[6] Bahl R 1999 Fiscal Decentralization As Development Policypublic Budg. Financ. Juornal Volume 19 Pages: 3-125

[7] Mankiw N G 2007 Macroeconomics (Jakarta: Erlangga)

[8] Sukirno S 2006 Economic Development: Processes, Problems and Policy Basis (Jakarta: Prenada Media Group)

[9] Kresnandra, Ngurah Agung, Erawati N M A 2013 The Effect of Local Taxes and Retribution on the Unemployment Rate with Capital Expenditures as Moderating Variables Udayana Univ. Account. E-Journal Vol 5.

[10] Setiyawati, Anis and Hamzah A 2007 Analysis of the Influence of Local Own Revenue, General Allocation Funds, Special Allocation Funds, and Development Expenditures on Economic Growth, Poverty, and Unemployment": Path Analysis Approach Indones. J. Account. Financ. Vol. 4 Pg, 211-228

[11] Novita 2012 The Influence of Local Taxes, Regional Retribution and Regional Expenditure Harmony on Economic Welfare in Regencies / Cities in Bali Province (Udayana University. Denpasar)

[12] Adi P H The Relationship Between Regional Economic Growth, Development Expenditures and Local Own Income. Accounting National

[13] Ghozali, I. \& Latan H 2015 Konsep, teknik dan aplikasi smartPLS (Semarang: Badan Penerbit Universitas Diponegoro.) 